\title{
ANALYSIS OF ELECTROTECHNICAL PROPERTIES OF INNOVATIVE HIGH-TEMPERATURE WIRES FOR OVERHEAD POWER TRANSMISSION LINES
}

LUSHCHIN S.P. Cand. of Phys.-Mathem. Sciences, associate professor, Department of Physics, Zaporizhzhya National Technical University, Zaporizhzhia, Ukraine, e-mail: luschin@zntu.edu.ua;

BOROVSKIH A.V. Masters of the Department of Electrical Machines and Apparatuses of the Zaporizhzhya National Technical University, Zaporizhzhia, Ukraine, e-mail: aayy6491@ gmail.com;

BOROVSKIH M.V. Masters of the Department of Electrical Machines and Apparatuses of the Zaporizhzhia National Technical University, Zaporizhzhia, Ukraine, e-mail:, kalbkab96@gmail.com;

Purpose. Determination of the capacity of wires of overhead power transmission lines based on innovative materials without changing the currently used structures, as well as the possibility of increasing the voltage class of overhead transmission lines when using wires based on aluminum-zirconium materials.

Methodology. Analytical method for determining the throughput capacity of overhead power transmission lines. Comparative analysis of electrical characteristics of wires of overhead power transmission lines.

Findings. The possibility of increasing the capacity of overhead power transmission lines while maintaining the wire cross-section, using an innovative material based on an aluminum-zirconium alloy, has been proved. The reduction of the weight of the wire based on innovative materials is justified, while maintaining the current throughput. The advantages and disadvantages of European wire structures for overhead power transmission lines are revealed using innovative material based on an aluminum-zirconium alloy. The optimal design of wires based on the innovative material of the aluminum-zirconium alloy for overhead transmission lines, permissible for use on the territory of Ukraine, has been determined.

Originality. The expediency of using the traditional designs of the wires of overhead power transmission lines has been proved, in the case of using innovative material. The possibility of increasing the voltage class of overhead power transmission lines using wires based on aluminum-zirconium materials has been substantiated.

Practical value. The results are obtained regarding the electrical resistance of overhead power transmission lines to peak loads, taking into account the low costs of modernization with the use of an innovative material based on an alloy of aluminum and zirconium. The use of innovative material creates conditions for increasing the voltage class of overhead power transmission lines, which allows increasing the transmitted power to the consumer. The use of materials based on aluminum-zirconium alloys makes it possible to carry out measures for the reconstruction of electric supply networks without replacement of supports and additional work on land allocation, as in the case of reconstruction without increasing the voltage line class of power lines, and in case of increasing the voltage class.

Keywords: overhead power transmission line; aluminum alloyed with zirconium; throughput; brands of wires.

\section{INTRODUTION}

High-voltage overhead transmission lines in the coming decades will continue to determine the development of both the world and domestic electric power industry.

The current state of Ukraine's high-voltage transmission lines mirrors the economic situation in the country. In order to overcome the problems in the current economic situation, many ideas have been proposed through energy saving for power supply system's [1] - [2].

The degree of physical aging of the existing fleet of high-voltage overhead electric lines depends on the commissioning of new facilities. Simple mathematical calculations show that if you commission new equipment to increase the power of the transmission systems by half every six years ( $8 \%$ of new equipment per year), then $8 \%$ of the network equipment is older than 30 years. If the renewal of the network park is $4 \%$ per year, then the share of equipment older than 30 years will be $29 \%$. Taking into account the requirements of GOST 839-80 [3] on the continuity of the performance of wires based on aluminum wires, the lack of renewal of capacities for 50 years may begin to be critical for the entire electric system of Ukraine.

Already, we can say that the solution of this problem through an extensive way is almost hopeless. To solve this technical problem, it seems necessary to differentiate the task of updating the fleet of electricity transmission capacities. It is technically feasible and affordable to conduct a survey of the residual load-bearing capacity of the masts of overhead power transmission lines (OPTL) in order to decide whether to perform routine maintenance instead of completely replacing them. The basis for this is the emergence of the possibility of using innovative designs of lightweight wires based on aluminum alloys 
doped with zirconium [4] - [8].

There are two tasks: the renewal of existing overhead lines in connection with their wear and tear and the increase in capacity through the commissioning of new transmission lines. The use of aluminum alloys allows you to solve these two tasks simultaneously, using existing masts of transmission lines. As a rule, the cross section of the power line wires is read out taking into account peak loads. At the same time, these loads are only a few hours a day, the rest of the time the wire cross-section is used inefficiently. The solution to this problem is to increase the thermal stability of the wire, allowing to increase the transmitted power during peak loads due to a higher permissible operating temperature.

One of the directions of modernization of the infrastructure of the electric power networks of the overhead line is the use of new thermally stable materials that must combine high electrical conductivity and sufficient strength, which persists after heating up to $240^{\circ} \mathrm{C}$. Since at these temperatures the crystallographic structure of undoped aluminum is highly disordered, it is not possible to create heat-resistant wires based on aluminum grades of the type A5E and A7E. The solution is the creation of low-alloyed aluminum alloys with the addition of zirconium [9]- [10].

The indicators of quality, reliability and efficient operation of the united energy system of Ukraine directly depend on the functioning and condition of overhead transmission lines. According to data for 2017 in Ukraine, the length of the $0.4 \mathrm{kV}$ transmission line amounted to $449,832 \mathrm{~km}$, and the voltage of $6-10 \mathrm{kV}$ to $332,568 \mathrm{~km}$, in addition, there is a tendency for an annual increase in the length of the line. There is a need to increase the efficiency of power systems, which is achieved by increasing the nominal network voltage [9].

The task can be solved by choosing a new and effective direction in the development of power transmission systems, which is based on scientifically based technical solutions using modern methods and technologies.

The directions and ways of solving this task in the context of reforming the relations of property in the energy sector are determined by the technical policy of the Ministry of Energy and Coal Industry of Ukraine, approved by the protocol of the scientific and technical council of September 14, 2016, as a set of tools, which are obliged to implement the provisions of the Law of Ukraine of 16.10.1997 №575 / 97 - BP "About electric power engineering" [11]. This law provides for the creation by the state of conditions for the development and enhancement of the technical level of the electric power industry.

The papers [12] - [13] show the actual and projected volumes of electricity consumption in Ukraine by groups of consumers for the period up to 2025 (Table 1).
Table 1. Actual and projected electricity consumption in Ukraine and by consumer groups up to 2025

\begin{tabular}{|c|c|c|c|c|c|}
\hline $\begin{array}{l}\text { Consum- } \\
\text { er groups }\end{array}$ & 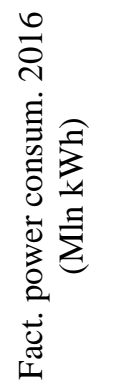 & 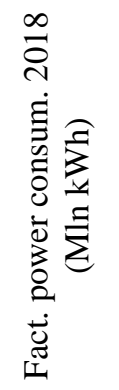 & 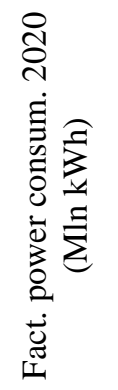 & 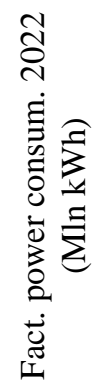 & 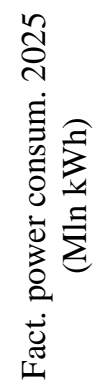 \\
\hline $\begin{array}{l}\text { Electrici- } \\
\text { ty supply } \\
\text { to con- } \\
\text { sumers }\end{array}$ & 101868 & $\begin{array}{l}11553 \\
9\end{array}$ & $\begin{array}{l}12593 \\
8\end{array}$ & $\begin{array}{l}3223 \\
5\end{array}$ & $\begin{array}{l}1643 \\
94\end{array}$ \\
\hline $\begin{array}{l}\text { (+) In- } \\
\text { crease } \\
/ \text { (-) Re- } \\
\text { duction } \\
\text { from the } \\
\text { previous } \\
\text { year }\end{array}$ & $-1,6$ & 0,7 & 0,9 & 0,5 & 1,2 \\
\hline Industry & 41979 & 47613 & 51898 & $\begin{array}{l}5449 \\
3 \\
\end{array}$ & $\begin{array}{c}6774 \\
6 \\
\end{array}$ \\
\hline & \multicolumn{5}{|c|}{ including the main branches: } \\
\hline Fuel & 4031,8 & $\begin{array}{l}4113, \\
2\end{array}$ & 4208,3 & $\begin{array}{l}4280, \\
1\end{array}$ & $\begin{array}{l}4457, \\
9\end{array}$ \\
\hline $\begin{array}{l}\text { Metallur- } \\
\text { gical }\end{array}$ & 27978 & 27116 & 4208,3 & $\begin{array}{l}4280, \\
1\end{array}$ & $\begin{array}{l}2743 \\
9 \\
\end{array}$ \\
\hline $\begin{array}{l}\text { Chemical } \\
\text { and pet- } \\
\text { rochemi- } \\
\text { cal }\end{array}$ & 1282 & 1454 & 1584 & 1664 & 2068 \\
\hline $\begin{array}{l}\text { Machine- } \\
\text { building }\end{array}$ & 2853 & 3235 & 3527 & 3703 & 4604 \\
\hline $\begin{array}{l}\text { Building } \\
\text { materials }\end{array}$ & 2048,8 & $\begin{array}{l}2047, \\
5\end{array}$ & 2055,7 & $\begin{array}{l}2022, \\
8 \\
\end{array}$ & $\begin{array}{l}2075, \\
8\end{array}$ \\
\hline $\begin{array}{l}\text { Food and } \\
\text { pro- } \\
\text { cessing }\end{array}$ & 4078,4 & $\begin{array}{l}4315, \\
9\end{array}$ & 4428,8 & $\begin{array}{l}4477, \\
6\end{array}$ & $\begin{array}{l}4663, \\
6\end{array}$ \\
\hline $\begin{array}{l}\text { Agricul- } \\
\text { tural }\end{array}$ & 2298 & $\begin{array}{l}4315, \\
9\end{array}$ & 4428,8 & $\begin{array}{l}4477, \\
6 \\
\end{array}$ & $\begin{array}{l}4663, \\
6\end{array}$ \\
\hline Transport & 6684,4 & $\begin{array}{l}6535, \\
0\end{array}$ & 6561,1 & $\begin{array}{l}1622 \\
8 \\
\end{array}$ & $\begin{array}{l}6461, \\
1\end{array}$ \\
\hline Building & 749,1 & 766,8 & 773,7 & 767,5 & 793,9 \\
\hline $\begin{array}{l}\text { Popula- } \\
\text { tion }\end{array}$ & 31552 & 35787 & 39008 & $\begin{array}{l}4095 \\
8\end{array}$ & $\begin{array}{l}5091 \\
9 \\
\end{array}$ \\
\hline
\end{tabular}

The process is replaced by the morally and physically worn-out equipment at the present time is rather slow. The volume of such equipment in Ukraine is by various estimates from 40 to $80 \%$. At present, this process has 
slowed down even more. As a result, the loss of electricity is growing, besides, given the current situation in Ukraine, the question arises of the prospects for the development of an overhead transmission line. This is due to increased energy consumption.

However, the increase in demand for electricity in conditions of difficulties with land allocation determines the need to increase the capacity of existing lines and reduce power losses.

\section{II.ANALYSIS OF LAST RESEARCHES}

In the publication of D. Zotov [5] and V.N. Kuryanova [6] conducted a comparison of air power transmission wires from innovative material in the constructions shown in Fig. 1.

a)

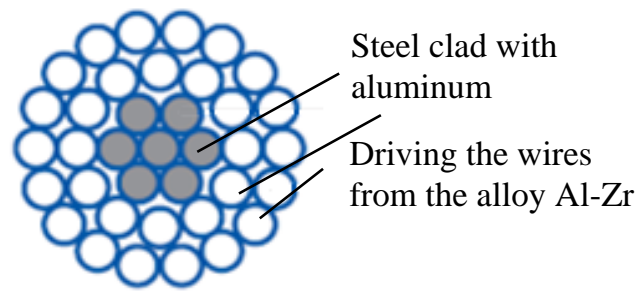

б)

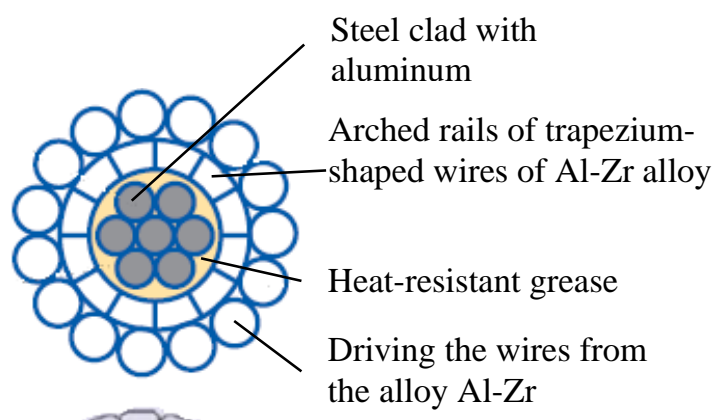

B)

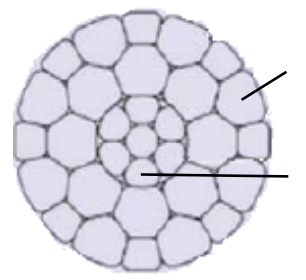

Current-conducting veins

from an aluminum allov

Carrier core

г)

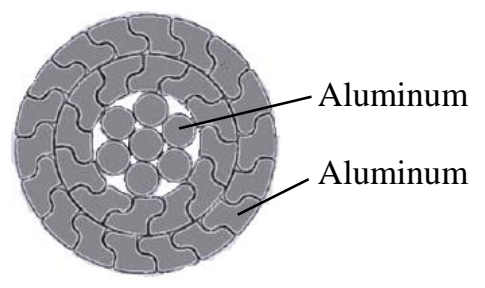

Figure 1. Construction of wires of type a) ASPT; b) ASPTs; c) ASVT; d) AERO-Z.

Electrotechnical aluminum and aluminum-alloy alloys, doped with zirconium, have a significant difference in properties. The resistivity of aluminum zirconium alloys is somewhat higher than that of aluminum. This is also fixed in the norms for wires [3], [14], [15]. In the works [4], [5], [8], [16], researchers have been informed about the possibility of reducing the resistance of the wires of OPTL on the basis of Al-Zr alloys to the wires of the brand AC by using new design solutions. However, all considered innovative designs of OPTL wires are not based on existing national regulatory documents in Ukraine. In this regard, their application in Ukraine is extremely difficult. Therefore, comparative studies of the properties of the wires of the overhead lines made on the basis of aluminum and alumina-conium alloys in the context of the current regulatory documents for the regulatory design of the OPTL wires will enable us to compare the properties of the materials under study under the same conditions of design solutions and also to substantiate the technical feasibility the use of OPTL wires in the current legislation.

Properties of heat-resistant wires for overhead lines on the basis of aluminum alloys doped with zirconium were studied earlier by a wide range of researchers [4] [8]. They compared these innovative products with traditional wires based on electrical aluminum. However, in all of these publications, aluminum and high-temperature wires were compared in various versions of the design. As it seems to us, the design has a significant effect on the technical properties of the wires. In [12], the wires of new design types were compared on the basis of innovative materials in relation to the properties of wires in a traditional design based on traditional materials. Data given by these authors do not allow us to evaluate separately the effect of using a new material (AlZr) on the properties of products. For a more complete evaluation of the actual new material in this article, we consider the properties of new materials in the construction of wires in accordance with GOST 839-80 [3] and JEC 3406: 1995.

\section{FORMULATION OF THE WORK PURPOSE}

The purpose of this paper is to determine, on the basis of available data on the properties of aluminum and aluminum-zirconium materials, the range of technical applicability of OPTL wires based on innovative materials for overhead transmission lines without changing the currently used designs, as well as the justification of the possibility of upgrading the voltage rating of overhead power lines using aluminum-zirconium-based wires.

\section{EXPOUNDING THE MAIN MATERIAL AND RESULTS ANALYSIS}

The basis for this was the construction of a wire of the AC type in accordance with GOST 839-80 [3]. The results of calculations for wires of high-voltage lines of the same section, obtained on the basis of the initial data and the above-mentioned standards, are shown in Fig. 2. A comparison of these data shows that the throughput for wires based on wires from a heat-resistant alloy of the AT brand is significantly increased (from 1.7 to 2.3 times, depending on the selected wire grade) compared to the AC wire.

Based on the above material, it can be seen that innova- 
tive heat-resistant wires of various designs allow to significantly increasing the transmission capacity of power lines due to higher permissible current loads.

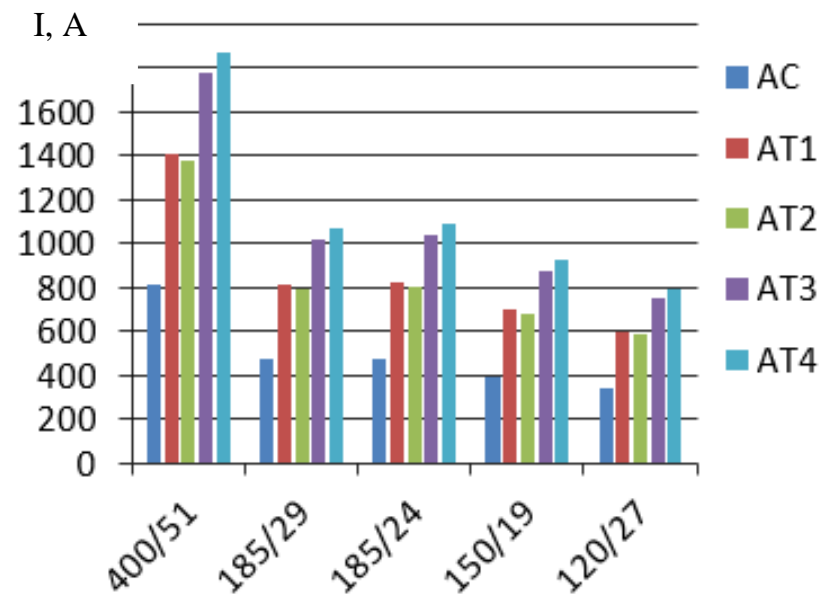

Figure 2. Limiting currents for wires of the brand $\mathrm{AC}$ on the basis of different materials.

The ordinate shows the current, A; the wire crosssection is indicated along the abscissa, the first value corresponds to the aluminum part, and the second corresponds to the steel part of the wire, $\mathrm{mm}^{2}$; AC $\neg$ when using conventional aluminum, AT1, AT2, AT3, AT4 - using aluminum-zirconium instead of pure aluminum.

When replacing an aluminum wire in wires of the $\mathrm{AC}$ type with an aluminum zirconium wire, it also increases the capacity of the line, which can lead to a favorable economic effect.

Reducing the section of the wire, while maintaining the current load, will lead to a reduction in the amount of material expended.

The preservation of the wire cross section with the use of innovative material makes it possible to increase the load of the overhead line. However, this method of reconstructing OPTL is more problematic, since it is necessary to take into account the distance between the wires when the voltage of the overhead line is increased, which is limited by the structure of the existing support.

Proceeding from this, the calculation and selection of the cross-section of the OPTL wires based on the AT wires was made, the admissible current for which is compared with the permissible current of the wires of the AC of the nominal section. The obtained data are presented in Table. 2.

Analyzing the data of various manufacturers on the significant increase in the cost of heat-resistant wires [5], compared to wires based on electrical aluminum and technological features of manufacturing heat-resistant wires [9], [10], it can be noted that technology manufacturing of heat-resistant wires almost completely coincides with the technology of aluminum wires. According to the research of the above-mentioned authors, the same equipment is used. There are two differences. The first is the introduction of a zirconium ligature into an aluminum melt. The second is a long-term (no less than 10-20 hours) heat treatment (up to $450{ }^{\circ} \mathrm{C}$ ). Given the small amounts of zirconium introduced $(0.35 \ldots 0.45$ mass $\%)$, doping with zirconium can't give a multiple increase in cost. It seems that the most significant contribution to the cost price is made by thermal processing. According to the data of the only manufacturer of heat-resistant wires on the territory of Ukraine LLC Krok-GT (Zaporozhye), the duration of heat treatment can be substantially reduced by complex alloying of the aluminum zirconium melt. The complex doping increases the rate of decomposition of the solid solution of zirconium in aluminum to the $\mathrm{Al}_{3} \mathrm{Zr}$ phase and, thus, the heat treatment time is shortened and its conditions are facilitated.

We estimate the transmission capacity of the transmission line as a function of the increase in voltage. Power, which is transmitted by the network, is determined by the formula:

$$
S=\sqrt{3} U_{n} J F
$$

where $\mathrm{S}$ is the transmission power, $\mathrm{U}_{\mathrm{n}}$ is the nominal line voltage, $\mathrm{J}$ is the permissible current density, and $\mathrm{F}$ is the cross-sectional area of the wire.

Table 2. Comparison of technical characteristics of wires based on aluminum wires and wires of AT grades under the condition of the same current-leading capacity.

\begin{tabular}{|c|c|c|c|c|c|}
\hline $\begin{array}{c}\text { Characteris- } \\
\text { tic }\end{array}$ & 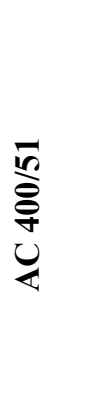 & 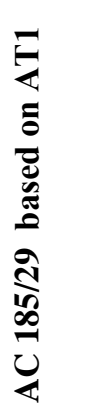 & 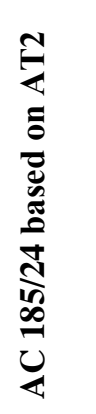 & 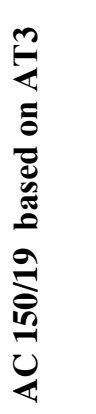 & 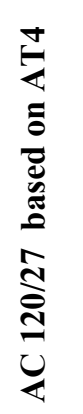 \\
\hline $\begin{array}{c}\text { Diameter, } \\
\text { mm }\end{array}$ & 27,5 & 18,8 & 18,9 & 16,8 & 15,4 \\
\hline Section, $\mathrm{mm}^{2}$ & 445,1 & 210 & 211,2 & 166,8 & 140,6 \\
\hline $\begin{array}{c}\text { Resistance, } \\
\text { Ohm / km }\end{array}$ & $\begin{array}{c}0,073 \\
3\end{array}$ & $\begin{array}{c}0,159 \\
1\end{array}$ & $\begin{array}{c}0,15 \\
4\end{array}$ & $\begin{array}{c}0,204 \\
6\end{array}$ & $\begin{array}{c}0,25 \\
31\end{array}$ \\
\hline $\begin{array}{l}\text { Breaking } \\
\text { force, } \mathrm{kN}\end{array}$ & 120 & 62 & 58 & 46 & 49 \\
\hline $\begin{array}{l}\text { Weight with- } \\
\text { out lubrica- } \\
\text { tion, kg }\end{array}$ & 1490 & 728 & 705 & 554 & 528 \\
\hline
\end{tabular}

Let us consider the case of a double increase in the voltage in the transmission line, i.e. $\mathrm{U}_{2 \mathrm{n}}=2 \mathrm{U}_{\mathrm{n}}$. The permissible current density in this case does not change, nor does the wire cross-sectional area. Then: 


$$
\frac{S_{n}}{S_{2 n}}=\frac{\sqrt{3} U_{n} J F}{\sqrt{3} U_{2 n} J F}=2 .
$$

Thus, the increase in transmission capacity is directly proportional to the increase in voltage in the transmission line.

We estimate the voltage drop in the line of electroreduction at a double increase in the voltage in the line by the formula:

$$
\Delta U=\frac{(P R+Q X)}{U^{2}},
$$

where $\mathrm{P}$ is the active power of the line, $\mathrm{R}$ is the line resistance, $\mathrm{Q}$ is the reactive line power, and $\mathrm{X}$ is the reactance of the line.

With the same load (transmitted power), with a twofold increase in voltage across the line, we will have:

$$
\frac{\Delta U_{n}}{\Delta U_{2 n}}=\frac{U_{n}^{2}}{U_{2 n}^{2}}=\frac{1}{4} .
$$

Consequently, a double increase in the voltage on the line leads to a fourfold decrease in the voltage drop in the line.

The loss of power in the line can be represented as:

$$
\Delta P=3 I^{2} R .
$$

With the same load, doubling the voltage in the line will result in:

$$
\frac{\Delta P_{n}}{\Delta P_{2 n}}=\frac{\frac{S_{n}^{2}}{U_{n}^{2}} R}{\frac{S_{2 n}^{2}}{U_{2 n}^{2}} R}=\frac{1}{4}
$$

Consequently, the power losses in the line are also reduced by a factor of four with a double increase in line voltage.

These considerations are confirmed by the data of presented in Table. 3.

However, based on Ohm's law, increasing the voltage in the power line leads to an increase in the amperage. Consequently, the possibility of increasing the voltage and transmitted power is limited by the value of the permissible current load. The foregoing allows us to recommend the use of aluminum zirconium materials for the production of wires for overhead lines in order to carry out a set of measures to reduce losses in overhead lines and increase transmission capacity.

Thus, based on the data obtained, it can be concluded that the use of OPTL wires based on aluminum zirconium wires is possible in two versions: firstly, the recon- struction of the transmission line, based on the reduction in the mass of innovative wires, but the invariance of the transmitted power, and the second option - a multiple increase in the transmitted power without changing the supports.

Table 3. Relative power losses

\begin{tabular}{|c|c|c|c|}
\hline \multirow{2}{*}{$\begin{array}{c}\text { Section, } \\
\mathbf{m m}^{\mathbf{2}}\end{array}$} & \multicolumn{3}{|c|}{$\begin{array}{c}\text { Loss of electrical energy in relation to } \\
\text { the amount of electricity that has been } \\
\text { supplied to the grid,\% }\end{array}$} \\
\cline { 2 - 4 } & $6 \mathrm{kV}$ & $10 \mathrm{kV}$ & $20 \mathrm{kV}$ \\
\hline 35 & 3,98 & 1,47 & 0,36 \\
\hline 50 & 3,05 & 1,09 & 0,27 \\
\hline 70 & 2,16 & 0,78 & 0,19 \\
\hline 95 & 1,54 & 0,56 & 0,14 \\
\hline 120 & 1,25 & 0,45 & 0,11 \\
\hline 150 & 1,05 & 0,38 & 0,09 \\
\hline 185 & 0,79 & 0,28 & 0,07 \\
\hline 240 & 0,61 & 0,22 & 0,05 \\
\hline
\end{tabular}

In accordance with the requirements of IEC 62420 , heat-resistant wires must be manufactured with a gap between the steel core and the aluminum zirconium wires (see Fig. 1, b). Constructively, this can be achieved only if the profiled wires are used. This causes a rise in the cost of making the wire. Consider how technically justified this is.

The creation of a wire with a gap was intended to transfer the entire mechanical load to the steel core. In this case, the wire ceases to work as a composite material made of steel and aluminum wires. Its mechanical properties are determined by the properties of the steel core (coefficient of thermal expansion (CTE), modulus of elasticity, etc.), so a smaller CTE of steel determines a smaller sag due to a smaller elongation with increasing operating temperature. Comparative characteristics of the wire sag, depending on the achieved operating temperature on the basis of the data of are shown in Fig. 3.

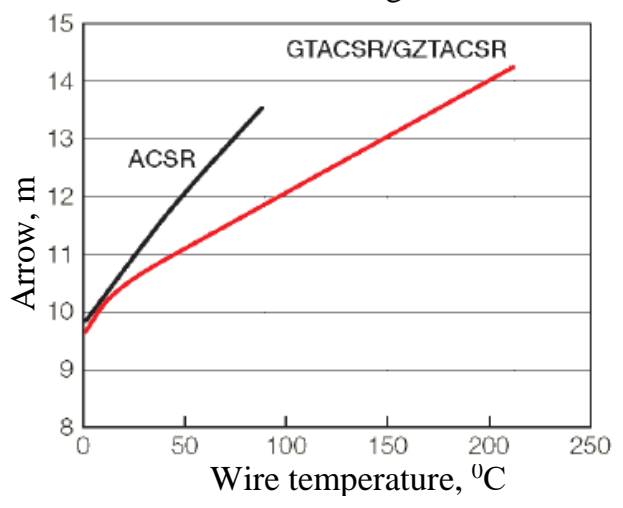

Figure 3. Dependence of the sagging arrow on the temperature for a wire with a gap and an $\mathrm{AC}$ wire.

The curve in black represents the dependence for the 
ACSR wire (Aluminum Conductor Steel Reinforced), the curve in red - the dependence for the wire from the innovative material of the brand GTACSR and GZNFCSR.

However, a more complex design of the wire leads to a complication of the technology of its manufacture. At the same time, the use of such a design necessitates the use of more sophisticated technology for the installation of wires and, as a consequence, the need to develop and use special equipment and fittings. This requirement is due to the need to fix the wire to the insulators behind the steel core, since the traditional fastening minimizes all the positive advantages of this design. The same causes are also due to a more complicated repair of the wire, which does not exist in Ukraine. All this together causes the need for more qualified personnel.

It can be assumed that it was these considerations that guided Lumpi-Berndorf, making the decision to produce TACSR (Thermally-resistant Aluminum-alloy Conductor Steel Reinforced) wires on the territory of the European Union based on the standard [14]. Structurally, these wires correspond to wires of the brand AC.

The classic aluminum wires of the overhead lines are structurally identical to the TACSR / ACS and (Z) TACSR / HACIN wires. There is the possibility of mounting these wires with the help of already known types of armature, the production of which is adjusted and put on stream. As a consequence, the need to master the new installation technology, as well as the purchase of equipment and the upgrading of the skills of the workforce, is no longer necessary. Thus, the company LumpiBerndorf during the installation and repair of the wire uses the same methods as for installing and repairing the standard AC wire. However, it is worth noting the need to use specially designed valves for operation at high temperatures.

\section{V.CONCLUSION}

The possibility of increasing the capacity of overhead power transmission lines while maintaining the wire cross-section, using an innovative material based on an aluminum-zirconium alloy, is proved.

The design of the wires according to IEC 62420 has a number of advantages over the classical design. However, the transition to the use of this structure is difficult. The construction of the wire in accordance with GOST 839-80 with the replacement of aluminum by aluminum, dispersed by nano-particles $\mathrm{AlZr}_{3}$, is able to withstand the growing loads in the power supply network.

Heat resistant wires based on aluminum-zirconium have already been used and standardized by the United States and in the European Union. However, the construction of wires based on these standards is not the most optimal for their use on the territory of Ukraine.

Using the new material allows you to increase the capacity of the overhead power line while maintaining the wire section (more than twice), or reduce the mass of active wire material by $40 \%$ without reducing the voltage class.

The optimal design of the wires based on the innovative material from the aluminum-zirconium alloy for electric transmission lines, permissible for use on the territory of Ukraine, is determined.

To implement and use heat-resistant wires in Ukraine, it is necessary to implement their production and solve problems associated with the release and registration of existing regulatory materials.

The article was received 07.03.2018

\section{АНАЛІЗ ЕЛЕКТРОТЕХНІЧНИХ ВЛАСТИВОСТЕЙ ІННОВАЦІЙНИХ ВИСОКОТЕМПЕРАТУРНИХ ПРОВОДІВ ДЛЯ ПОВІТРЯНИХ ЛІНІЙ ЕЛЕКТРОПЕРЕДАЧІ}

ЛУЩИН С.П.

БОРКОВСЬКИХ А.В.

\section{БОРКОВСЬКИХ М.В}

канд. фіз-матем. наук, доцент кафедри фізики Запорізького національного технічного університету, Запоріжжя, Україна, e-mail: luschin@zntu.edu.ua;

магістрант кафедри електричні машини і апарати Запорізького національного технічного університету, Запоріжжя, Україна, e-mail: aаyу6491@gmail.com;

магістрант кафедри електричні машини і апарати Запорізького національного технічного університету, Запоріжжя, Україна, e-mail: kalbkab96@gmail.com;

Мета роботи. Визначення пропускної здатності проводів повітряних ліній електропередачі на основі інноваційних матеріалів без зміни використовуваних в даний час конструкцій, а також можливості підвищення класу напруги повітряних ліній електропередачі при використанні проводів на основі алюмінієво-циирконієвих матеріалів.

Методи дослідження. Аналітичний метод визначення пропускної здатності проводів повітряних ліній електропередачі. Порівняльний аналіз електротехнічних характеристик проводів повітряних ліній електропередачі.

Отримані результати. Доведено можливість збільшення пропускної спроможності повітряних ліній електропередачі при збереженні перетину дроту, при використанні інноваційного матеріалу на основі сплаву 
алюміній-иирконій. Обтрунтовано зниження маси дроту на основі інноваиійних матеріалів при збереженні пропускної здатності по току. Виявлено переваги та недоліки європейських конструкиій проводів для повітряної ліній електропередачі при використанні інноваційного матеріалу, на основі сплаву алюміній-иирконій. Визначено оптимальну конструкцію проводів на основі інноваційного матеріалу зі сплаву алюміній-цирконій для повітряних ліній електропередач, допустима для використання на території України.

Наукова новизна. Доведено доиільність використання традиційних конструкиій проводів повітряних ліній електропередачі, в разі застосування інноваційного матеріалу. Обтрунтовано можливість підвищення класу напруги повітряних ліній електропередачі при використанні проводів на основі алюмінієво-цирконієвих матеріалів.

Практична цінність. Отримано результати щодо електричної стійкості повітряних ліній електропередачі до пікових навантажень, з урахуванням незначних витрат на модернізацію при використанні інноваційного матеріалу на основі сплаву алюмінію і иирконію. Використання інновачійного матеріалу створює умови для підвищення класу напруги повітряних ліній електропередач, що дозволяє проводити збільшення переданої потужності до споживача. Використання матеріалів на основі алюмінієво-иирконієвих сплавів дозволяє проводити заходи щодо реконструкиї мереж електричного постачання без заміни опор та додаткових робіт щодо землевідведення, як у випадку проведення реконструкиії без збільшення класу напруги лінії електропередач, так і в разі підвищення класу напруги.

Ключові слова: повітряна лінія електропередачі; алюміній легований иирконієм; пропускна здатність; марки проводів.

\section{АНАЛИЗ ЭЛЕКТРОТЕХНИЧЕСКИХ СВОЙСТВ ИННОВАЦИОННЫХ ВЫСОКОТЕМПЕРАТУРНЫХ ПРОВОДОВ ДЛЯ ВОЗДУШНЫХ ЛИНИЙ ЭЛЕКТРОПЕРЕДАЧИ}

ЛУЩИН С.П.

БОРКОВСКИХ А.В.

БОРКОВСКИХ М.В. магистрант кафедры электрические машины и аппараты Запорожского национального технического университета, Запорожье, Украина, e-mail: kalbkab96@gmail.com;

Цель. Определение пропускной способности проводов воздушных линий электропередачи на основе инновационных материалов без изменения используемых в настоящее время конструкций, а также возможности повышения класса напряжения воздушных линий электропередачи при использовании проводов на основе алюминиево-ииркониевых материалов.

Методы исследования. Аналитический метод определения пропускной способности проводов воздушных линий электропередачи. Сравнительный анализ электротехнических характеристик проводов воздушных линий электропередачи.

Полученные результаты. Доказана возможность увеличения пропускной способности воздушных линий электропередачи при сохранении сечения провода, при использовании инновационного материала на основе сплава алюминий-цирконий. Обосновано снижение массы провода на основе инновационных материалов при сохранении пропускной способности по току. Выявлены преимущества и недостатки европейских конструкиий проводов для воздушной линий электропередачи при использовании инновационного материала, на основе сплава алюминий-цирконий. Определена оптимальная конструкция проводов на основе инновационного материала из сплава алюминий-цирконий для воздуиных линий электропередач, допустимая к использованию на территории Украины.

Научная новизна. Доказана целесообразность использования традииионных конструкиий проводов воздушных линий электропередачи, в случае применения инновационного материала. Обоснована возможность повышения класса напряжения воздушных линий электропередачи при использовании проводов на основе алюминиево-ииркониевых материалов.

Практическая ценность. Получены результаты относительно электрической стойкости воздуиных линий электропередачи к пиковым нагрузкам, с учетом незначительных затрат на модернизаиию при использовании инновационного материала на основе сплава алюминия и ииркония. Использование инновационного материала создает условия для повышения класса напряжения воздушных линий электропередач, что позволяет 
проводить увеличение передаваемой мощности к потребителю. Использование материалов на основе алюминиево-цииркониевых сплавов позволяет проводить мероприятия по реконструкции сетей электрического снабжения без замены опор и дополнительных работ по землеотводу, как в случае проведения реконструкции без увеличения класса напряжения линии электропередач, так и в случае повышения класса напряжения.

Ключевые слова: воздушная линия электропередачи; алюминий, легированный иирконием; пропускная способность; марки проводов.

\section{REFERENCES}

[1] Dyachenko, V. (2015). Creation of energy saving program for power supply systems. Electrical Engineering And Power Engineering, 1, 70-76. doi:http://dx.doi.org/10.15588/1607-6761-2015-1-12 (in Russian).

[2] Tsyplenkov, D., Krasovskiy, P. (2015). Methods and means of technical losses reduction of electricity in the elements of power supply systems. Electrical Engineering And Power Engineering, 1, 77-82. doi:http://dx.doi.org/10.15588/1607-6761-2015-1-13 (in Russian).

[3] GOST 839-80. Provoda neizolirovannye dlja vozdushnyh linij jelektroperedachi. Tehnicheskie uslovija. dejstvujushhij s 1999 - 01- 01 - IPK izdatel'stvo standartov, [Uninsulated wires for overhead power lines. Technical conditions. operating since 1999 - 01-01 - IPC publishing standards],1981, 22s.

[4] Klimenko, M.M., Ggorova, O.Ju. (2011). Analiz efektivnosti vikoristannja isnujuchih zasobiv pidvishhennja propusknoï zdatnosti linij elektroperedach. [Analysis of the efficiency of the use of existing means of increasing the transmission capacity of transmission lines]. Sistemi ozbroennja $i$ vijs'kova tehnika, 1, 96-100. (in Ukranian).

[5] Zotov, D.R. (2015). Linii jelektroperedachi. Povyshenie peredavaemoj moshhnosti.[ Power lines. Increase in transmitted power]. Novosti JelektroTehniki, 2(92), 42-44. (in Russian).

[6] Kur'janov, V.N., Sultanov, M.M.,. Fokin, V.A., Timashova, L.V. (2016), Innovacionnye vysokojeffektivnye provoda dlja linij jelektroperedachi. [Innovative high-performance wires for power lines]. Jenergija edinoj seti, 4(27), 70-78. (in Russian).

[7] Alekseev, B.A. (2009). Povyshenie propusknoj sposobnosti vozdushnyh linij jelektroperedachi i primenenie provodov novyh marok.[ Increase in the capacity of overhead power lines and the use of wires of new brands]. Elektro. Jelek-trotehnika, jelektrojenergetika, jelektrotehnicheskaja promyshlennost', 3, 45-50. (in Russian).

[8] Petrova, E.V., Bigun, A.Ja., Gorjunov, V.N., Girshin, S.S., Bubenchikov, A.A. (2013). Raschjot pogresh-nostej opredelenija poter' jelektricheskoj jenergii $\mathrm{V}$ provodah povyshennoj propusknoj sposobnosti iz-za ne uchjota atmosfernyh i rezhimnyh faktorov. [Calculation of errors in determining the losses of electrical energy in wires with increased throughput, because of not taking into account at- mospheric and regime factors]. Omskij nauchnyj vestnik, 2(120), 191-197.

[9] Matveeva, I.A. (2014). Issledovanie i razrabotka tehnologii proizvodstva aljuminievoj katanki $\mathrm{s}$ dobavkoj cirkonija sposobom nepreryvnogo lit'ja i prokatki s cel'ju poluchenija iz nee termostojkih provodov LJeP. [Research and development of technology for the production of aluminum rod with zirconium additive by the method of continuous casting and rolling with the purpose of obtaining heatresistant wires from it], 149s.

[10]Dostaeva, A.M. (2015). Obosnovanie sostava i rezhima termoobrabotki provodnikovyh $\mathrm{Al}-\mathrm{Zr}$ splavov, poluchaemyh $\mathrm{v}$ vide katanki. [Substantiation of the composition and regime of heat treatment of conductor Al-Zr alloys, obtained in the form of wire rod], 109.

[11]Zakon Ukrainy ot 16.10.1997 № 575/97- VR «Pro elektroenergetiku». - Rezhim dostupu: http://zakon4.rada.gov.ua/laws/main/575/97-vr. Nazvanie s ekrana.

[12]Ciganenko, B.V., (2017). Efektivnist' roboti rozpodil'nih elektrichnih merezh pri pidvishhenni ïh klasu naprugi. [Efficiency of distribution electric networks at increase of their class of voltage], 271.

[13]Ciganenko, B.V., Kirik, V.V. (2016). Osoblivosti funkcionuvannja rozpodil'nih merezh seredn'ogo klasu naprugi ta ïh perevedennja na naprugu $20 \mathrm{kV}$, [Features of the functioning of distribution networks of the middle class voltage and their transfer to voltage of $20 \mathrm{kV}$ ]. Hydropower of Ukraine, 3-4, 7-13. (in Ukranian).

[14](2007). IEC 62004. Thermal-resistant aluminium alloy wire for overhead line conductor. first edition 2007-02 - international electrotechnisal commission, 16.

[15]ASTM B941-16. Standard Specification for Heat Resistant Aluminum-Zirconium Alloy Wire for Electrical Purposes.

[16]Timashova, L.V., Nikiforov E.P., Nazarov, I.A., Merzljakov, A.S., Ermoshina, M.S., Kachanovskaja, L.I., Konstantinova, E.D., Romanov, P.I., Ko-losov, S.V., Shkapcov. V.A. (2014). Povyshenie nadjozhnosti vozdushnyh linij jelektroperedachi pri primenenii provodov novogo pokolenija. [Increasing the reliability of overhead power lines when using new generation wires]. Jenergija edinoj seti, 5(16), 614. (in Russian). 